ACTA UNIVERSITATIS LODZIENSIS

FOLIA LITTERARIA POLONICA 5(35) 2016

http://dx.doi.org/10.18778/1505-9057.35.02

Michał Drożdż*

\title{
Hate Speech in Media Discourse
}

\section{Introduction}

This article is an attempt to find an answer to the question of whether socalled hate speech in the media has the character of recounting facts and reflecting the social and cultural reality, or serves other purposes, for example the coaxing and manipulative creation of a desired reality, which is inscribed in the commercial and persuasive media functionality.

The contemporary media and political discourse has a linguistic and metalinguistic character. The media language on the one hand reflects the crudeness and brutality of the public and political discourse, however, on the other hand, it itself contributes to the tabloidization of social communication. One of the elements of the phenomenon is so-called hate speech, which is used to label certain utterances, acts, attitudes and public life activities. It is an increasingly common phenomenon used at the metalinguistic level, which evaluates media language.

These two levels of the public discourse: linguistic and metalinguistic, more and more often intersect, blurring the borders between what is a linguistic description of reality and what is a metalinguistic performative creation.

The phenomenon is especially visible in the context of hatred present in public life. The media recipient, however, cannot clearly distinguish between the description of the factual hateful account of public life and the linguistic labelling of the utterance which is inconvenient for the opposite party of the discourse. The latter notion is expressly classified as "hate speech".

The analyses below are an attempt to present some manipulative tendencies in using the label "hate speech". The author tries to confront the question whether such labelling is to cleanse public life from the linguistic manifestations of hatred, or whether this labelling is more about creating and liberating the hatred

* Ks. dr hab., prof. UPJPII, e-mail: michal.drozdz@upjp2.edu.pl; Pontifical University of John Paul II, Faculty of Social Sciences, Institute of Journalism and Social Communication; ul. Grodzka 40, 31-004 Kraków. 
necessary to power and feed the media show. From the perspective of media axiology, the semiological perspective, as well as media linguistics, I am trying to answer the question, what is the role of media language in forming and promoting real attitudes of hostility and hatred, and reversely - how do the cultural and media tendencies shape media hate speech. I am not going to focus primarily on the analysis of the material aspect of language, but rather look critically at some media tendencies which create new linguistic forms as agents of negative values.

\section{Hate speech in the context of freedom of speech}

Not going into the ethical details of understanding hatred as a negative value, which is contrary to love and a person's well being, the opening sphere of the reflection should be concisely organised.

Hatred is not only a matter of emotional antipathy, but it is also a demonstration of the voluntary rejection of another person's attitude, language or activity.

The nature of hatred is determined by the aim of the rejection: it is either a threat towards oneself (odium abominationis) or because one feels aversion to another person, bearing them malice (odium inimicitiae). In both cases one nullifies another person's values and dignity.

The one who feels a spontaneous antipathy towards someone because they have done great evil or harmed others, experiences inner pain but not hatred. Also the one who condemns evil that is found within a fellow human being, because they perform it, does not hate if the person is not reprimanded. The disapprobation of what is truly evil and malicious within the fellow man even constitutes a part of the true love of the fellow being.

The so-called hate speech concept has only recently appeared in public and media discourse. The notion perfectly agrees with the mechanism of labelling the opponents' views. In 2003 a book by Sergiusz Kowalski and Magdalena Tulli entitled Zamiast procesu. Raport o mowie nienawiści (Eng. Instead of a trial. A report on hate speech) was published ${ }^{1}$. It is a richly documented work on hate speech in the right-wing media. The book exposes the analytical productivity of the perspective which is imposed by hate speech. The analysis, however, has a fundamental flaw, as it identifies hate speech as typical solely for right-wing views. The authors of this book use this concept - mostly describing the activities of the right-wing media - at the same time not paying attention to the use

${ }^{1}$ S. Kowalski, M. Tulli, „Zamiast procesu. Raport o mowie nienawiści”, W.A.B., Warsaw 2003. 
of language, which corresponds with the definition of hate speech, by other political parties, mostly left-wing ones. This attitude reflects the general tendency, in which the "hate speech" concept is often used - especially by some groups of politicians - unreliably, instrumentally, and in a manipulative way, which is manifested in that the same word spoken by political opponents is stigmatised, whereas when spoken by supporters it is approved of as a symptom of eloquence and being lettered.

In the discourse analysis of hate speech the following questions arise:

- Is hate speech an expression of individual opinions or a political device fuelling hatred?

- Is conveying every, even the most extreme opinion, good for public debate?

The debate about hate speech covers concepts related to a conflict of two values: freedom of speech and respect for human dignity. According to CBOS's [Public Opinion Research Center] research, only " $16 \%$ of the respondents believe that «Freedom of speech guarantees the ability to express one's opinions freely, even if these opinions are perceived by some people or groups as offensive, deriding or harmful», while the majority (73\%) does not share such views"2.

In the discussion about media freedom, there sometimes appear voices of ignorance and miscomprehension. An utterance of a publicist of one of the most prominent daily newspapers can serve as an example:

I think, however, that if someone is a supporter of freedom of speech, they also have to be supporting freedom of filthy, foul, stupid and harmful speech. Someone who states that they are a supporter of freedom of speech, however, on the condition that this will be beautiful, wise and noble speech, is, as a matter of fact, a supporter of censorship ${ }^{3}$.

To name a responsible ethical behaviour as censorship borders on absurdity. Ethics is not censorship. Ethics protects and reflects the world of values, and primarily protects human values and dignity.

Thomas Jefferson, the co-author of the First Amendment to the United States Constitution, from the beginning had no illusion that freedom of speech, which is good, can also serve evil. Here is a fragment of his utterance when he was already president:

I deplore the putrid state into which our newspapers have passed, and the malignity, the vulgarity, and mendacious spirit of those who write for them... These ordures

${ }^{2}$ CBOS, „Społeczna percepcja przemocy i mowy nienawiści. Komunikat z badań, http:// www.cbos.pl/-SPISKOM.POL/2007/K_074_07.PDF [access: 14.06.2015].

${ }^{3}$ W. Orliński, „Wolność słowa, także kłamliwego”, Gazeta Wyborcza 2006, 1.03, p. 19. 
are rapidly depraving the public taste. However, it is evil for which there is no cure: the condition of our freedoms is the freedom of the press, and that cannot be reduced without destroying it ${ }^{4}$.

Jefferson - as many liberals and democrats in his times and now - saw no cure for the evils of the media. There is a remedy, however: freedom of speech has to be closely linked with the responsibility for speech, thus it has to be restricted by concerns for other people's welfare. What is more - today most experts claim that freedom without responsibility is not freedom at all.

Freedom of the media, which can rise to the position of a myth in the consciousness of many readers, listeners and viewers, is automatically identified with truthfulness and objectivity of information. The media should be free (and I am not judging the actual state of the media in Poland, but I am emphasising the postulatory character of this statement), however, it does not mean that it can be free from responsibility.

No freedom, including freedom of speech, is absolute: it encounters a boundary in the shape of the duty to respect others' dignity and their legitimate freedom. One should not write, create and broadcast programmes if they damage the truth: and I mean not only the factual truth that is conveyed, but also the "truth about a human being", a person's dignity in all dimensions ${ }^{5}$.

The Pontifical Council for Social Communications in a document entitled Ethics in Communications writes:

The presumption should always be in favor of freedom of expression, for "when people follow their natural inclination to exchange ideas and declare their opinions, they are not merely making use of a right. They are also performing a social duty" (Communio et Progressio, 45). Still, considered from an ethical perspective, this presumption is not an absolute, indefeasible norm. There are obvious instances - for example, libel and slander, messages that seek to foster hatred and conflict among individuals and groups, obscenity and pornography, the morbid depiction of violence - where no right to communicate exists. Plainly, too, free expression should always observe principles like truth, fairness, and respect for privacy ${ }^{6}$.

John Paul II during his pilgrimage to Poland in 1991 also spoke of the responsibility for one's speech:

${ }^{4}$ M. Iłowiecki, „Pilnowanie strażników. Etyka dziennikarska w praktyce”, Fronda PI, Warsaw 2012, p. 158.

${ }^{5}$ See: Jan Paweł II, „Prawdziwi chrześcijanie i znakomici dziennikarze”, http://www.opoka.org. pl/biblioteka/W/WP/jan_pawel_ii/przemowienia/dziennikarze_04062000.html [access: 20.09.2006].

${ }^{6}$ Papieska Rada ds. Srodków Społecznego Przekazu, „Etyka w mediach”, Vatican City 2000, No. 23. 
[...] so the responsibility for one's words is exceptional because they have the power of testimony - they either testify the truth and are good for a human being or they do not testify the truth, they are its negation, and therefore they mean evil for the human being, although they can be presented and altered in such a way that they seem good. It is called manipulation? ${ }^{7}$.

Manipulation is not an unambiguous concept, and that is why its assessment is also equivocal and even controversial. When it comes to the moral assessment of manipulation one should pay attention to the intended aim and the means by which one is trying to achieve it. These are somewhat moral attributes of the manipulative fact. Every type and character of a manipulation, whatever it is, is indeed a human manipulation, which essentially implies an ethically negative assessment of such actions. The human is a subject of manipulation. It is determined by the character of manipulation and its increasing diversity. Manipulation is an intentional and secret action, by means of which a false image of a certain reality is imposed on a person or a group of people.

Media hate speech is used in manipulative processes where it does not reflect reality, but creates it anew, as in quasi-documentaries like: docu styles, docu soap, docu show, for example, the Polish show Trudne sprawy, etc.

\section{The media creation of an artificial reality of hatred}

The assessment of the hate speech which is present in the media must involve knowledge of the media functionality.

Along with the original function of reflecting the world, the media work more and more actively in creating reality. As a result of the process, one finds a change in the competences of the creators and the recipients of media communications. The creator and sender of the communication does not convey an objective meaning in it, but is reduced to an inventor of contexts for the receiving creation of the world, and becomes one of the interpretative contexts.

The media visualisation of reality consists of a permanent confrontation of the "quotidian reality" with the "media reality". People constantly experience artificial worlds by means of the media. This experience begins to question the exclusivity of the real world, and later on it blurs the sense of reality, to the extent that the "clear distinction between the quotidian reality and the media reality is no

7 Jan Paweł II, „Homilia wygłoszona w czasie Mszy św. w Olsztynie, 6 czerwca 1991 roku”, in: Jan Paweł II, „Pielgrzymki do Ojczyzny. Przemówienia i homilie”, 3. ed., Wydawnictwo Znak, Cracow 2005, p. 669. 
longer possible". A long-term effect of media hate speech is the creation of artificial realities of hatred, which is accomplished through different media processes and through several stages.

Firstly, the true reality is shaped according to the rules of the media. Media hate speech adopts performative features, which create an artificial world of media hatred. This world permeates the real world of interpersonal relations (the media is responsible for the emotions connected with hatred, for example in the evaluation of political opponents).

Secondly, the media world and reality intersect, relativizing and blurring the borders of the reality more and more in the process. The recipient of the media loses the criteria by which they differentiate between the reality of hatred and its depiction and description in the media.

Thirdly, the media influence the very shape of reality. Today many real political events are staged from the very beginning because of the possibility of being presented in the media. The media shape real emotional stages of hatred within the reality that exists beyond the media. This reality is increasingly sated with elements of the media hate speech.

Fourthly, the media change the time and space conditioning of real human life and human communication possibilities. Thanks to the media, a structure of omnipresence without a distinguished presence is created. Time and space, traditionally fundamental coordinates of our world, become vestigial. The change within these conditions proves the thesis that the reality of media hatred is largely a media structure.

Fifthly, the media blur the line between reality and a staged event or a simulation. The experience of simulation increasingly becomes a model for real events, and the reality is more and more often assessed along with the mental image of the media representation. Hence, one may believe that the simulated hatred, which is presented in the media, is a part of real life ${ }^{8}$.

This mechanism and the possibilities of the new electronic media are used by different groups, as well as by social and cultural structures in order to create their own images. At the back of the show, which happens by means of the media, there are hidden constructivist assumptions and tools used to create the "artificial worlds", which, indeed, play a positive part when they serve for fun and entertainment, however, which also, when used within social structures, can become a tool of manipulation.

When analysing the constructivist tendencies visible in the creation of media hate speech, one cannot omit the cultural fact of the postmodern influence, which denies the objective connection between the signifier and the signified. Jacques Derrida

\footnotetext{
${ }^{8}$ See: M. Drożdż, „Logos i ethos mediów. Dyskurs paradygmatyczny filozofii mediów”, Wydawnictwo Diecezji Tarnowskiej Biblos, Tarnow 2005, pp. 328-334.
} 
and Jean Baudrillard deny the existence of the signified - the meaning in itself ${ }^{9}$. According to such a conception, the signifier and the signified are not related to any of the implied realities. There is thus no objective reality, no external experience apart from the very process of indication, because every experience or every reality is only an effect of the semantic discourse. The language does not carry objective meanings, but it becomes a tool of the communicational discourse, in which there is a whole multitude of communications constructed by the subjects. As a consequence, the media language becomes a tool of a game, of a discourse, of the subjectivity and discretion of human thought structures, as well as of the autonomy in their creation, cognising and use in practice. This way, with no liability and no responsibility, one can create media hate speech, which is a peculiar game of negative values.

\section{Some varieties of linguistic destruction}

Some negative tendencies of cultural mentality are reflected in the mass media culture, and these promote banality, vulgarity, crudeness, absolute liberty, etc. They undoubtedly contribute to the blurring of the lines between good and evil, deepening the state of ethical confusion. This tendency has a negative influence on the moral sensitivity of a human being, in such that many people do not use the concept of evil in everyday speech, but instead they describe it with substitutes like: incongruity, lack of propriety, inverity, insubordination, order violation, etc., which partly justify the evil or trivialise it. The media use the so-called visibility method, often excessively exposing the negative phenomena, and making them the main feature of their own appeal. The advancing ignorance and trivialisation of evil can be a consequence of such activity. The process can lead to a hypertrophy of the insensibility to evil, which means there appears a systematic substitution of the good for the worse and the worse for the bad, a substitution of the excess for ordinariness and ordinariness for abnormality, etc. It is a replacement which, in the end, blurs the lines between good and evil. Such a substitution is so easy because of the assistance of language which trivialises evil, for example the word "to kill" is replaced by the expression "to cause death out of compassion", "a lie" is replaced by "an unexplainable matter", "subjugation" becomes "creating a new imagination", "pornography" becomes "the language of the body". This linguistic practice does not testify that the awareness of the evil declines, but rather that the evil is trivialised, and that it is the capability of a correct ethical evaluation that recedes. It is sometimes observed that tragedies and scandals awaken the conscience from this ethical confusion in evaluation.

\footnotetext{
${ }^{9}$ See: M. Drożdż, „Media. Teorie i fikcje”, Wydawnictwo Jedność, Kielce 2005, pp. 53-86.
} 
The Pontifical Council for Social Communications in a document entitled Ethics in Communications presents potential spheres of the media threats, among which hate speech plays a significantly negative part:

The media also can be used to block community and injure the integral good of persons: by alienating people or marginalizing and isolating them; drawing them into perverse communities organized around false, destructive values; fostering hostility and conflict, demonizing others and creating a mentality of "us" against "them"; presenting what is base and degrading in a glamorous light, while ignoring or belittling what uplifts and ennobles; spreading misinformation and disinformation, fostering trivialization and banality. Stereotyping - based on race and ethnicity, sex and age and other factors, including religion - is distressingly common in media ${ }^{10}$.

Fostering hostility in the media is achieved mostly by means of hate speech, which will always be against media ethics.

Media hate speech is also a part of the media show. Media communications (conveying information) are created within the entertainment convention: radio - the dynamics of fact simplification, television - the show, press - tabloids. This media "amusement to death" and the triumph of "technopoly" are evocatively presented in the publications of Neil Postman.

Of course - Postman writes - to say that television is entertaining is merely banal. Such a fact is hardly threatening to a culture, not even worth writing a book about. It may even be a reason for rejoicing. Life, as we like to say, is not a highway strewn with flowers. [...] But what I am claiming here is not that television is entertaining but that it has made entertainment itself the natural format for the representation of all experience $[\ldots]$. The problem is not that television presents us with entertaining subject matter but that all subject matter is presented as entertaining, which is another issue altogether. No matter what is depicted or from what point of view, the overarching presumption is that it is there for our amusement and pleasure. That is why even on news shows which provide us daily with fragments of tragedy and barbarism, we are urged by the newscasters to "join them tomorrow"

There is a danger that every content of a message can be submitted to the absolute entertainment process, which is based on commercialism, a good show and on cheap amusement. It does not put love, truth and upbringing in the first place, but instead - as Hans Arp calls it - it praises the "collective ecstasy and

\footnotetext{
${ }^{10}$ Papieska Rada, op. cit., No. 13.

${ }^{11}$ N. Postman, „Zabawić się na śmierć. Dyskurs publiczny w epoce show-businessu”, transl. L. Niedzielski, Wydawnictwo Muza, Warsaw 2002, p. 130.
} 
fast money making"12. It is worth noticing that the processes of degradation and elimination of the rational discourse from the media described by Postman are not determined by the very "nature" of media communications, and thus are not determined by the linguistic forms, but rather by the messages of the communications and the processes of media commercialisation. Postman shows that in the omnipotent era of the media and "show business"13 the life presented or impersonated on the screen appears to be more important than the reality, and that media emotions effectively reduce the world of human experiences. One of the most frequent tools of the media used in order to play with the emotions is astonishing the recipient with extreme forms and messages full of negative values, which consist primarily of hostility and hatred.

\section{A conscience responsible for speech quality}

The search for tools and measures to restrict media hate speech indicates the need for media ethics, which no longer serves only as a postulate of moral reflection upon the media, but also as a necessity conditioned by many different factors, and which serves the truth and the well being of the human and the community. The human being and the community experience many cultural and media challenges, and all the more need a clear orientation not to get lost within the aspects which are "hostile towards humans" (violence, aggression, fanaticism, human dignity degradation, hatred), as well as to be reassured about the validity of the owned or created world of values.

The moment one seeks grounds and conditionings for freedom of speech, which forms the boundaries in which also hate speech can appear, one has to clearly state that it is achieved primarily within the inner human sphere, in the sphere of individual decision-making and of the choices conditioned by ethical rules upholding values. It is achieved in the inner human sphere, within one's conscience. Freedom of speech is thus a matter of human conscience. It is indicated by different terms such as: "subjective moral consciousness", "individual responsibility", "acting according to one's conscience", "acting according to one's inner belief". Many of these terms, which designate the human being as the only and final source of evaluation, are an expression of the advancing subjectivisation and relativisation of ethics. The fact that people make subjective choices is not the problem. The ethical evaluation, which is achieved in the human

12 As cited in: S. Babolin, "Produzione di senso, Hortus Conclusus", Rome 1999, p. 156.

${ }^{13}$ See: N. Postman, „Das Zeitalter des Showbusiness”, in: „Kursbuch Medienkultur. Die maßgeblichen Theorien von Brecht bis Baudrillard”, ed. C. Pias, J. Vogl, L. Engell, O. Fahle, B. Neitzel, DVA, Stuttgart 2000, pp. 223-233. 
conscience, is always personal and subjective. The problem, however, lies in the question whether a person who chooses and acts "according to one's conscience" has a clear conscience - a properly shaped one. The notion of humans having their "consciences shaped according to the truth" should be the basic concern of every morality. A conscience which is certain and true should be thus the basis for a proper moral evaluation. Such conscience becomes - in our understanding - the most important media instance. It allows us to actualise human liberty, freedom of speech, and thus to explore and convey the truth in the context of other values ${ }^{14}$.

\section{Conclusion}

Several conclusions appear in the context of media hate speech, which have the character of a postulate and which are connected with a few open questions.

1) More and more often language does not carry objective meanings, but it becomes a tool of the communicational discourse. The meaning of words is created within the communicational discourse. Thereby, the media language becomes the tool of a game, of a discourse, of the subjectivity and discretion of human thought structures, as well as of the autonomy in their creation, cognising and use in practice. The question, thus, is posed to what extent the media communications, which create images of the world, reflect the actual state of difficult social relations presented by means of hate speech, and conversely - to what extent do they influence the creation of conflicts, quarrels and hatred in the real human world.

2) Secondly, the axiological pluralism and diversity of the assessment criteria imply also the diversity of forms, messages, context and borderlines of media communications. One has to consider if, and to what extent, this diversity should be perceived as the cognitive and axiological richness of culture and of a human being. There also appears the question of whether the plurality should be perceived as a variety of communicational discourses on the basis of a fundamental respect for values and dignity of every human being, and not as a chaotic crossing of the boundaries of good taste, decency and elementary respect for people.

3) Thirdly, the processes of media averaging and simplifying the perception systematically eliminate the need for intellectual effort in the process of media message reception, as well as depriving people of independent thinking. Is it possible that in such a situation the human as a recipient will not consolidate the attitude of conformism, the intellectual indolence, the spiral of silence?

\footnotetext{
${ }^{14}$ See: M. Drożdż, „Osoba i media. Personalistyczny paradygmat etyki mediów”, Wydawnictwo Diecezji Tarnowskiej Biblos, Tarnow 2005, pp. 175-192.
} 
Will they not, at the same time, abandon the individual responsibility for the shape of one's logos and life ethos when entering and using the - preferred by the media - world of entertainment, which is produced by means of the language of quarrel and feud?

4) Fourthly, the media prefer the new quality of media communications and a new quality of the perception, which are conditioned mostly by the formula of playfulness, lightness, easiness and entertainment. Hence, one has to question if it is possible for a human, who lives in such a world of playing with hatred, to build relations with other people on the basis of love and respect for human dignity.

\section{Bibliography}

Babolin S., "Produzione di senso, Hortus Conclusus", Rome 1999.

CBOS, „Społeczna percepcja przemocy i mowy nienawiści. Komunikat z badań, http://www. cbos.pl/-SPISKOM.POL/2007/K_074_07.PDF [access: 14.06.2015].

Drożdż M., „Logos i ethos mediów. Dyskurs paradygmatyczny filozofii mediów”, Wydawnictwo Diecezji Tarnowskiej Biblos, Tarnow 2005.

Drożdż M., „Media. Teorie i fikcje”, Wydawnictwo Jedność, Kielce 2005.

Drożdż M., „Osoba i media. Personalistyczny paradygmat etyki mediów”, Wydawnictwo Diecezji Tarnowskiej Biblos, Tarnow 2005.

Iłowiecki M., „Pilnowanie strażników. Etyka dziennikarska w praktyce”, Fronda PI, Warsaw 2012.

Jan Paweł II, „Homilia wygłoszona w czasie Mszy św. w Olsztynie, 6 czerwca 1991 roku”, in: Jan Paweł II, „Pielgrzymki do Ojczyzny. Przemówienia i homilie”, 3. ed., Wydawnictwo Znak, Cracow 2005.

Jan Paweł II, „Prawdziwi chrześcijanie i znakomici dziennikarze”, http://www.opoka.org.pl/biblioteka/W/WP/jan_pawel_ii/przemowienia/dziennikarze_04062000.html [access: 20.09.2006].

Kowalski S., Tulli M., „Zamiast procesu. Raport o mowie nienawiści”, W.A.B., Warsaw 2003.

Orliński W., „Wolność słowa, także kłamliwego”, Gazeta Wyborcza 2006, 1.03, p. 19.

Papieska Rada ds. Środków Społecznego Przekazu, „Etyka w mediach”, Vatican City 2000, No. 23.

Postman N., „Das Zeitalter des Showbusiness”, in: „Kursbuch Medienkultur. Die maßgeblichen Theorien von Brecht bis Baudrillard”, ed.. C. Pias, J. Vogl, L. Engell, O. Fahle, B. Neitzel, DVA, Stuttgart 2000, pp. 223-233.

Postman N., „Zabawić się na śmierć. Dyskurs publiczny w epoce show-businessu”, transl. L. Niedzielski, Wydawnictwo Muza, Warsaw 2002. 
Michał Drożdż

The Hate Speech in Media Discourse

(Summary)

This article is an attempt to seek answers to the question of whether so-called hate speech in the media constitutes a reporting of facts and reflects real social and cultural life or pursues other aims, for example: the persuasive and manipulative creation of a desired reality innate in the functioning of a commercial and persuasive media. The author attempts from the axiological perspective of the media, as well as from the semiological and linguistic perspectives, to answer the question of what the role of media language is in shaping and promoting real attitudes of hostility and hatred, and conversely, how cultural and media tendencies shape hate speech in the media. The author does not analyse the material aspect of language, but rather tries to look critically at certain trends shaping new forms of media language that bear negative values.

Keywords: hate speech, media, media ethics, hate, speech. 